\title{
The impact of rheumatoid arthritis on the economic situation of Polish households
}

\author{
Wptyw reumatoidalnego zapalenia stawów na kondycję ekonomiczna gospodarstw \\ domowych w Polsce
}

\author{
Jolanta Grygielska \\ Department of Epidemiology and Health Promotion, Institute of Rheumatology in Warsaw \\ Zakład Epidemiologii i Promocji Zdrowia Instytutu Reumatologii im. prof. dr hab. med. Eleonory Reicher w Warszawie
}

Key words: rheumatoid arthritis, cost of disease, household budget, survey.

Słowa kluczowe: reumatoidalne zapalenie stawów, koszty choroby, budżet domowy, badanie kwestionariuszowe.

\begin{abstract}
Summary
Objectives: Rheumatoid arthritis (RA) is a chronic disease which causes patient disability and affects the situation of the patient's household. On the one hand, the disease is associated with treatment costs and the need to adapt the patient's environment but on the other hand it limits the employment options available to the patients and their families. The purpose of this work is to evaluate the cost of rheumatoid arthritis and to verify whether the disease has an impact on the economic situation of households.

Material and methods: The survey study was conducted by professional surveyors between November 2009 and March 2010. The study included 1,000 respondents with diagnosed rheumatoid arthritis (RA) from the patient pool of 50 randomly selected Polish rheumatology outpatient clinics.

Results: The obtained results related to household budgets were compared with data available from the Central Statistical Office (GUS) for 2009 (desk research). The comparison indicates that RA actually affects the household budgets. RA patient households have reduced income levels as compared to the national average and their expenditures on healthcare per person are almost twice as high. While the average household expenditures related to healthcare amount to PLN 47.90, the expenditures of RA patient households reach PLN 93.37. Financial issues were reported by $49 \%$ of RA patient households as compared to $20 \%$ of households in general (acc. to GUS). Also, the assistance provided by third parties significantly affects the cost level.

Conclusions: The disease significantly limits earning options available to the patients and their families and at the same time it increases the costs related to treatment and patient disability. In order to reduce the socio-economic impact of the disease it is necessary to ensure early diagnosis and early onset of appropriate treatment.
\end{abstract}

\section{Streszczenie}

Cel pracy: Reumatoidalne zapalenie stawów (RZS), jako choroba przewlekła, stopniowo ograniczająca sprawność chorego, wpływa na kondycję ekonomiczną jego gospodarstwa domowego. Schorzenie to z jednej strony wymaga ponoszenia kosztów na leczenie i dostosowanie środowiska chorego, z drugiej natomiast ogranicza możliwości zarobkowe jego i jego rodziny. Celem pracy było oszacowanie kosztów RZS oraz wykazanie, czy choroba wpływa na kondycję ekonomiczna gospodarstwa domowego chorego.

Materiał i metody: Badanie kwestionariuszowe zostało przeprowadzone przez profesjonalnych ankieterów od listopada 2009 roku do marca 2010 roku. Objęło 1000 respondentów chorych na RZS spośród pacjentów 50 losowo wybranych poradni reumatologicznych w Polsce. Wyniki: Uzyskane wyniki w zakresie budżetów gospodarstw domowych zostały porównane z danymi opublikowanymi przez Główny Urząd Statystyczny (GUS) za rok 2009 (desk research). Porównanie wykazało, że zachorowanie na RZS wpływa na kondycję ekonomiczną gospodarstwa domowego chorych. Zaznacza się $w$ tych gospodarstwach ograniczenie dochodów w stosunku do przeciętnych i prawie 2-krotne zwiększenie miesięcznych wydatków na zdrowie przypadających na jedną osobę. W przeciętnym gospodarstwie wydaje się na zdrowie miesięcznie na jedną osobę 47,90 zł, w gospodarstwie chorego na RZS w tym samym czasie prawie 2-krotnie więcej, tj. 93,37 zł. Trudności finansowe dotyczą 49\% gospodarstw osób chorych na RZS, przy 20\% gospodarstw domowych zgłaszających takie trudności w badaniach GUS. Znaczny wpływ na koszty RZS ma pomoc osób trzecich.

Wnioski: Reumatoidalne zapalenie stawów ogranicza możliwości pracy zarobkowej chorego i jego najbliższych, a równocześnie zwiększa koszty związane z leczeniem i niepełnosprawnością chorego. W celu zmniejszenia kosztów społeczno-ekonomicznych choroby niezbędne są wczesna diagnoza i wprowadzenie odpowiedniego leczenia.

Address for correspondence:

Jolanta Grygielska, Department of Epidemiology and Health Promotion, Institute of Rheumatology, Spartańska 1, 02-637 Warsaw

Submitted: 26.02 .2013 


\section{Introduction}

It is estimated that in Poland rheumatoid arthritis (RA) affects $0.45 \%$ of the general population aged 19 and above, which translates to c. 131.5 thousand patients [1]. In 2002 the Institute of Rheumatology in cooperation with the National Institute of Public Health conducted a population survey to evaluate declared musculoskeletal complaints [2]. However, the research did not manage to estimate the population of RA patients since as many as $4 \%$ of the respondents claimed to have suffered from RA. WHO estimates from 2000 indicate that the actual incidence of RA is 0.3 $1 \%$ of the adult population [3]. The Central Statistical Office (Gtówny Urząd Statystyczny - GUS) has adopted the extended definition "osteitis and arthritis" which, according to national data, affects $5.6 \%$ of males and $11.8 \%$ of females [4]. Since in Poland no register of inflammatory rheumatic disease is available, all the data are estimated. No official data concerning the incidence of RA in Poland are available and therefore estimates will have to be used. The estimates published by Kobelt [1] are considered reliable. Based on the number of RA patients divided according to gender and age (3 age groups: 20-44 years, 45-64, 65 and above) in Sweden and Hungary, Kobelt has referred the ratios to the number of citizens in other EU countries who meet the above criteria.

According to statistical data published by the Social Insurance Institution (Zakład Ubezpieczeń Społecznych - ZUS), musculoskeletal diseases (including RA) were the third most common cause of incapacity for work (more common causes are cardiovascular system and mental disorders). Rheumatoid arthritis was also the third largest item in ZUS expenditures on pension benefits and the top item on the list of medical rehabilitation expenses (26.3\%), followed by injury, poisoning and cardiovascular system disorders [5, 6].

Evaluation of disease costs is significant from the perspective of both the patient and the health/social insurance systems. The cost of rheumatic diseases has been previously estimated in the Netherlands, where the relation between RA-related costs and disease duration has also been proved [7]. A comparative analysis of the cost of ankylosing spondylitis (AS) conducted in France, Belgium and the Netherlands showed that the average annual cost of the disease incurred by the patient amounts to approximately 1795 euro [8]. According to the comparison of healthcare systems adopted in Scandinavia and the impact of individual solutions on the cost of rheumatoid disease, the highest expenditures were identified in Iceland and Norway and the lowest in Sweden [9].

\section{Material and methods}

The survey study took place between November 2009 and March 2010 and was conducted by surveyors from the
Centre of Sociological Research (ORBS), Institute of Philosophy and Sociology, Polish Academy of Science. The study included 1,000 randomly selected patients with diagnosed RA under the care of local rheumatology outpatient clinics in Poland. In order to recruit respondents to the study, the Multi-Stage Cluster Sampling strategy was used. During the first stage of the study, 50 clinics were randomly selected according to the spatial distribution of rheumatology care in Poland. The clinics were divided into three categories according to the population size of the location (big cities with over 500 thousand inhabitants, cities of medium size with 50 to 499 thousand inhabitants, and small towns with less than 50 thousand inhabitants including villages) and two categories of clinic (hospital or another). In the second stage of sample definition, RA patients (ICD: M05 and M06) were randomly selected from patient populations in the selected clinics so that the average number of surveys was 20 per clinic (i.e. 1,000 nationwide). The survey was continued according to the same design until the aforementioned number of surveys had been reached.

Ethics approval of the research was obtained from the Bioethical Committee of the Institute of Rheumatology. All participants gave written informed consent. The privacy of the patients was protected by the coding of all data.

The study tools were questionnaires: for patients, for attending rheumatologists and for rheumatology clinic staff. The purpose of the survey for rheumatologists was to confirm patients' statements concerning treatment and evaluation of their condition. The purpose of surveys for rheumatology clinic staff was to define the clinic range and the number of patients provided with rheumatology care. This questionnaire was answered by the head of a clinic or a person designated by the head of the clinic. Each of the patient surveys comprised 126 questions with various specificity which were divided into four areas:

- costs related to treatment - 54 questions,

- other costs related to disease: change in lifestyle, care provided by third parties - 31 questions,

- the present health status of the respondent - 18 questions,

- household budget - 25 questions.

Additionally, a Health Assessment Questionnaire (HAQ) composed of 20 questions was used to evaluate the patient's ability to perform everyday life activities [10]. HAQ is the simplest tool for patient self-assessment which is commonly applied in quality of life evaluations. The respondents assessed their ability to perform 20 activities by selecting 4 levels of difficulty from "without any difficulty" (0) to "unable to do" (3). HAQ ratio > 2.25 is considered as "significant disability" and $\mathrm{HAQ} \geq 1$ as "clinical disability" [11]. 
The results pertaining to RA patients' household budget were compared to the data published by GUS in September 2010 [12] describing the situation of households in Poland in 2009. Additionally from all respondents a group of patients with declared certificated disability was selected. A disabled patient's household budget was compared to the data concerning the household budget of a disabled person published by GUS.

The budgets were compared as total numbers and according to the number of persons sharing the household, the main source of income and place of residence. In order to define the socio-economic situation of an average RA patient household and to compare the data against the information from GUS, the researchers calculated average and mean values for each category and each question based on the results of 1,000 surveys. The $\chi^{2}$ test was used to compare the data. The statistically significant level was defined at 0.95 which means $p \leq 0.05$.

\section{Results}

The response rate in this study was $61.6 \%$.

\section{Respondents}

As many as $83 \%$ of the total 1,000 respondents were female. The average respondent age was 60 years (standard deviation $=12.5$, median $=60$ years) .

The average disease duration in the study group was 16 years (standard deviation $=12$, median $=13$ years) and the average time from diagnosis was 13 years (standard deviation $=11$, median $=10$ years) .

\section{Household characteristics}

On average, a respondent household consisted of 2.56 persons. The basic sources of income were: retirement benefits (45\% of households), salary for professional work (32\%) and disability allowance (12\%). In the case of RA patients receiving disability allowance, the mean patient age when the allowance was granted was 44 years (standard deviation $=9.7$, median $=45$ years ).

\section{Income and quality of life assessment}

The average monthly income level per capita in RA patient households was PLN 953 while the income level in households with disabled patients was lower and amounted to PLN 8991. The subjective evaluation of households showed that $2.5 \%$ considered their living standard to be satisfactory, while financial issues were reported by $49 \%$ of all RA patient households and $60 \%$ of households with disabled patients.

\section{Expenditures}

\section{Food and accommodation}

The average expenditures on basic needs such as food and accommodation in respondents' household amount to PLN 474.30 per capita, which translates to $50 \%$ of household income (19\% on accommodation, 31\% on food). In households with a disabled person living with RA average expenditures on food and accommodation were lower than in the average RA household (PLN 468.26) and they accounted for $52 \%$ of income. When questioned about changes in diet related to RA, $65 \%$ of respondents claimed that their nutrition habits had changed. Notably, $23 \%$ of respondents claimed that their average spending on food had increased by PLN 1,300 per annum.

Spending on stimulants was calculated separately and amounted to $1.7 \%$ of household income, i.e. PLN 16.70 per person monthly.

\section{Communication and transport}

Spending on communication constituted $4.2 \%$ of income and $5 \%$ of monthly expenditures, amounting to almost PLN 40 per capita. Spending on transport was significantly higher and amounted to PLN 66.50. Changes related to mobility outside the household were reported by $54 \%$ of respondents and 20\% claimed that impaired mobility had increased their expenditures on transport by PLN 1,180 per annum on average.

Households with a disabled RA person reported spending PLN 38.19 on communication (4\% of income) and PLN 64.47 on transport (7\% of income).

\section{Health}

Health-related expenditures in RA patient households (including medication and diet supplements, chargeable medical and paramedical services, orthesis, medical rehabilitation and health resort stays, and chargeable patient care) amounted to $9.8 \%$ of income (PLN 93.37). The above expenditures were the third highest amount after food and accommodation costs. Households with a disabled RA patient reported higher spending amounting to PLN 103.20 (11.5\% of income).

\section{By regions of Poland}

The highest expenditures amount-wise were reported in the Central regions (Mazowieckie and Łódzkie), i.e. PLN 106 (113\% of the average value for RA patient households), and the lowest expenditures were reported in the Eastern

${ }^{1}$ Current (August 2013) average Exchange rate by National Bank of Poland (NBP): 1 PLN = 0.2372 EUR. 
regions (Podlaskie, Lubelskie, Podkarpackie, Świętokrzyskie), i.e. PLN 85 (91\% of the average). In both these regions health-related expenditures amounted to $10 \%$ of income.

\section{By location size}

The lowest expenditures were reported by residents from rural areas: $84 \%$ of the average (PLN 78.30). The highest expenditures were reported by residents of cities with populations between 200,000 and 499,000, i.e. PLN 147.30 (158\% of the average).

\section{By household size}

The highest level of health-related expenditures was identified in households run by a single person. These expenditures in a single person household amount to $16 \%$ of all expenditures (as compared to the average RA patient's household amount of $12 \%$ of all expenditures).

In single person households the patients spend on health an average of PLN 180.40 per month.

\section{Unpaid assistance provided by third parties}

As many as $69 \%$ of the respondents used assistance provided by third parties. The average per 1,000 respondents was 19.8 hours a week (2.8 hours a day). Constant care was required by $5 \%$ of responders. Patients who required care provided by others were usually assisted by their family members (93\% of them) while the least common assistance provider was the social welfare service (1\%).

The average HAQ level for 1,000 respondents was 0.8 (median $=0.6$ ). In patients with disease duration of at least
2 years, the average HAQ level was lower at 0.5 (median $=0.2$ ), while the highest level of 1.0 (median $=0.9$ ) was associated with disease duration of more than 10 years. Significant disability (HAQ ratio > 2.25) was identified in 5\% of respondents while $35 \%$ had clinical disability $(\mathrm{HAQ} \geq 1)$. Only $15 \%$ of patients claimed they did not experience any difficulties ( $\mathrm{HAQ}=0)$. The remaining patients (45\%) reported having some problems in everyday activities.

\section{Disability confirmed by law}

In this study $53 \%$ of patients had disability confirmed by law. Among them 35\% (19\% of all responders) held a certificate confirming significant disability, while 64\% (33\% of all responders) had moderate/mild disability levels. Notably, $1 \%$ of disabled respondents did not define the level of disability. Data of how disease duration contributes to increase in the level of disability are shown in Fig. 1.

\section{Adaptation of patient environment}

As many as $41 \%$ of respondents declared that they would adapt their environment under favorable conditions (if financially supported) and $45 \%$ considered that adaptation was not necessary. Another $4 \%$ of respondents considered that adaptation was necessary but they were too old to do it. However, $5 \%$ of patients remained undecided. Only $5 \%$ of 1,000 respondents (52 persons) stated that they had already adapted their environment.

During the 12 months preceding participation in this study, $7 \%$ of respondents (66/1,000 persons) purchased suitable bathroom equipment, $6 \%$ (61/1,000 persons) rearranged their bathrooms and 5\% $(48 / 1,000)$ bought

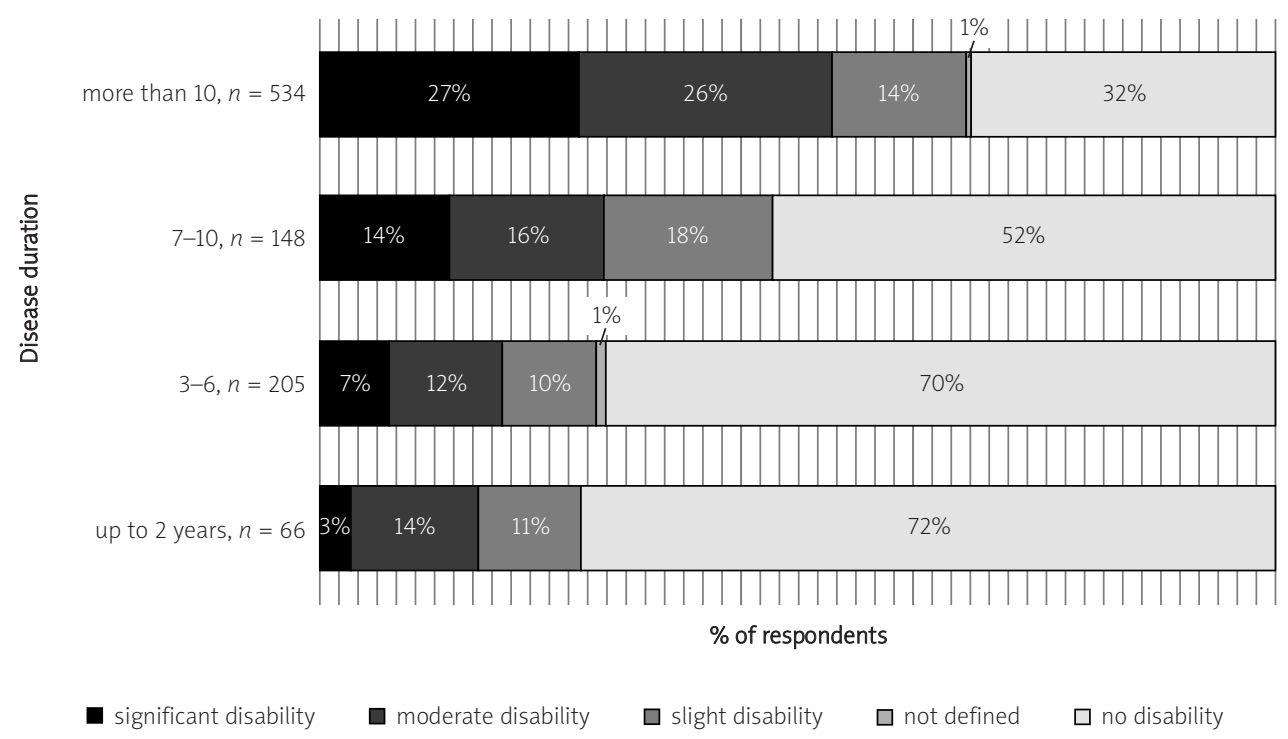

Fig. 1. Disabled respondents and disease duration according to respondents' declarations 
a dishwasher - these were the most frequent adaptations of the environment. Notably, $10 \%$ of respondents reported no adaptation in this time. Subsidies were used infrequently, e.g. the social welfare services subsidized bathroom rearrangements in 5 out of 61 cases (8\%). Walking aids were used by $30 \%$ of patients.

\section{Discussion}

Since the majority of study participants were female (83.5\%), their participation rate in this study was compared against other studies including RA patients. In similar studies, the female participation rate was 74-79\% [13-15]. The mean respondent age in our study (60 years) was also comparable with the results of other similar studies, where the average age of respondents was 57.4 [14], 58 [16] and 59 years [17].

The age structure of the study respondents was different to the age structure of the general population in Poland. In the 45-64 age group, the respondent rate was $21 \%$ higher (55\% vs. 34\%) and above 64 years the rate was higher by $18 \%$ (35\% vs. 17\%) [18]. The differences in patients' age structure are related to the clinical characteristics of RA.

The distribution of patients according to their places of residence was comparable to the national structure and the differences in individual groups were 1-2\%.

The study design included evaluation of RA influence on the life of patients and their family members by means of comparison to a control group with the same demographic background (age, gender, place of residence). The pilot study showed low efficacy of control group selection, which was also associated with a high additional cost. Therefore, we decided to rely on information gathered from patients and to include questions related to household budget in the RA patient survey. In this part of the questionnaire, the respondents defined the average level of income and expenditures per person in their households. The data were then compared to the information concerning the general population in Poland published by the Central Statistical Office (GUS) [11].

An average respondent household was smaller than the Polish average ( 2.56 vs. 2.90). Comparison in terms of basic sources of income showed that respondent households relied on social welfare benefits more often than the national average (retirement benefit - 45\% vs. $28 \%$, disability allowance $-12 \%$ vs. $7 \%$ ). This, in turn, resulted in a lower percentage of households which rely on salaries (32\% vs. $49 \%$ ).

The average monthly income level per capita in RA patient households was lower (by PLN 119) than the average Polish household, as compared to spendable income (PLN 953 vs. PLN 1,072). The average monthly expenditures in RA patient households were lower (PLN 791 vs. PLN 957). The economic situation of RA patient households was confirmed by the subjective assessment of their economic condition as compared to the national data. Financial issues

Table I. Comparison of monthly expenditures per capita in average Polish household according to GUS data, average RA patient household and average disabled person household (according to GUS data and in the study).

\begin{tabular}{|c|c|c|c|c|c|c|c|c|c|c|}
\hline \multirow[t]{3}{*}{ Item } & \multicolumn{5}{|c|}{ Average household } & \multicolumn{5}{|c|}{ Household with a disabled person } \\
\hline & \multicolumn{2}{|c|}{ GUS, $N=37302$} & \multicolumn{2}{|c|}{$\mathrm{RA}, N=1000$} & \multirow{2}{*}{$\begin{array}{l}\text { Significance } \\
\text { level } p\end{array}$} & \multicolumn{2}{|c|}{ GUS, $N=8447^{\star}$} & \multicolumn{2}{|c|}{ RA, $N=533$} & \multirow{2}{*}{$\begin{array}{c}\text { Significance } \\
\text { level } p\end{array}$} \\
\hline & PLN & $\%$ & PLN & $\%$ & & PLN & $\%$ & PLN & $\%$ & \\
\hline Food & 240.08 & 25.1 & 293.28 & 37.1 & $<0.0001$ & 233.34 & 28.5 & 291.08 & 37.8 & 0.0001 \\
\hline Accommodation & 188.03 & 19.7 & 181.02 & 22.9 & 0.0987 & 169.18 & 20.7 & 177.18 & 23.0 & 0.2558 \\
\hline Transport & 92.74 & 9.7 & 66.47 & 8.4 & 0.3201 & 63.98 & 7.8 & 64.47 & 8.4 & 0.7155 \\
\hline Leisure/culture & 76.35 & 8.0 & 24.00 & 3.0 & $<0.0001$ & 51.33 & 6.3 & 21.34 & 2.8 & 0.0008 \\
\hline Health & 47.90 & 5.0 & 93.37 & 11.8 & $<0.0001$ & 55.21 & 6.8 & 103.22 & 13.4 & $<0.0001$ \\
\hline Communication & 43.47 & 4.5 & 39.85 & 5.0 & 0.5846 & 37.41 & 4.6 & 38.19 & 5.0 & 0.6988 \\
\hline Stimulants & 26.06 & 2.7 & 16.67 & 2.1 & 0.4457 & 23.41 & 2.9 & 13.09 & 1.7 & 0.1329 \\
\hline Education & 11.44 & 1.2 & 21.19 & 2.7 & 0.0196 & 6.78 & 0.8 & 15.42 & 2.0 & 0.0623 \\
\hline Other & 230.61 & 24.1 & 55.17 & 6.9 & $<0.0001$ & 177.03 & 21.7 & 45.10 & 5.9 & $<0.0001$ \\
\hline TOTAL & 956.68 & 100.0 & 791.02 & 100.0 & - & 817.67 & 100.0 & 769.09 & 100.0 & - \\
\hline
\end{tabular}

*The number of disabled persons was calculated based on the structure ratio from 2010 
were reported by more RA patient households than the national average (29\% more than average, $49 \%$ vs. $20 \%$ ).

The most remarkable differences between RA patient households and the average Polish households concerned health and leisure/culture expenditures. An example of similar expenditure levels is spending on accommodation, with the difference between an RA patient household and an average Polish household being PLN 7.01 per person monthly (PLN 181.03 vs. PLN 188.02). The details concerning the structure of expenditures (absolute values and percentages) in an average RA patient household and an average Polish household are presented in Table I.

The results of this study have confirmed the hypothesis that the health-related costs per capita are higher in RA patient households (almost twice as high, 195\%) than the Polish average (PLN 93.37 vs. PLN 47.70). A comparison of health-related expenditures in average households and households with a disabled patient shows that the expenditures in disabled patient households were higher by $1.7 \%$ [both according to the Central Statistical Office (GUS) data and the results of this study].

The highest level of health-related costs in average households and in RA patient households were reported in the Central regions (PLN 65 vs. PLN 106), while the lowest costs were reported in the Eastern regions (PLN 40 vs. PLN 85).

The lowest health-related costs were reported by residents of rural areas (PLN 39.20 acc. to GUS). The average expenditures in RA patient household in a rural area amounted to PLN 78.30. This amounted to almost 200\% of health-related spending in an average rural household. RA patient households with the highest spending on health were located in cities with populations between 200,000 and 499,000. On the other hand, the highest health-related costs were identified in other households located in cities with populations of 500,000 or more (PLN 85.50, 179\% of the national average). This amounted to $92 \%$ of health-related costs in an average RA patient household.

In RA patient households, similarly to general Polish households, health-related expenditures were on average the highest in single person households. According to GUS, in Poland in a single person household these expenditures amounted to $7 \%$ of the total expenditures (vs. $5 \%$ in an average household in Poland). In this study in a single patient household this amounted to 16\% (vs. 12\% in the average household of an RA patient). Similarly to RA patient households, a higher number of persons per household (average Polish household) was connected with a lower percentage of health-related expenditures per person. This difference reached approximately 1 percentage point in households composed of 4, 5, 6 and more members. According to GUS data this amounts to 3.8-4.4\% in general households (average 5\%) and in this study 9.4-10.4\% (average 12\%).
Comparison of monthly spending per capita in an average household with a disabled person in Poland and in this survey indicated that health-related expenditures in a household with a disabled RA person amounted to PLN 103.20 and they were almost twice as high as in an average household with a disabled person in Poland (PLN 55.21).

The percentage of disabled patients was higher among RA patients as compared to the adult Polish population. According to GUS, in Poland significant disability was confirmed in $7 \%$ of the population as compared to $19 \%$ of respondents, while moderate and mild disability counted together was confirmed in 14\% vs. 33\%, respectively.

In many studies including RA patients, HAQ is used to evaluate the patient's ability to perform everyday activities. In the Dutch study (576 participants), the average HAQ score was 1.2. In their study, the HAQ score was compared to disease duration and amounted to 0.9 with duration of up to 2 years and 1.6 with duration of more than 10 years $[7,17,19]$. In the Belgian study (133 participants) patients with early RA (average duration of 0.5 year) had a HAQ score of 1.0 and patients with late RA (average 12.5 years) had a HAQ score of 1.7 [20]. Our data showed that the HAQ score was lower (average $=0.8$, median $=0.6$ ) and the results of HAQ analyzed against disease duration were better: 0.5 with duration of up to 2 years and 1.0 with duration of more than 10 years.

\section{Conclusions}

Rheumatoid arthritis has an impact on the economic situation of Polish households. Patient disability imposes a significant burden on their families. Therefore, it is crucial to initiate any action necessary to reduce the time to the disease diagnosis and the time to appropriate treatment onset. Progressive disability and the need to discontinue employment cause deterioration of the economic status of RA patient families, which must be counteracted at every stage of the disease.

\section{Acknowledgements}

The author of this article would like to thank all persons who assisted in its preparation, especially Bożena Moskalewicz, Małgorzata Happach and Katarzyna Świerkocka from the Institute of Rheumatology as well as Paweł Sztabiński, Franciszek Sztabiński and Teresa Żmijewska-Jędrzejczyk from the ORBS, for their considerable contribution to the preparation of the research questionnaire, and to Sanofi-Aventis for the unlimited grant for this research.

Source of funding: unrestricted research grant from Sanofi-Aventis. 


\section{References}

1. Kobelt G, Kasteng F. Access to innovative treatments In rheumatoid arthritis In Europe. October 2009; A report prepared for The European Federation of Pharmaceutical Industry Associations (EFPIA).

2. Raport z badania w Zakładzie Epidemiologii Chorób Reumatycznych „Nasze zdrowie, nasze dolegliwości”. Warszawa 2002. http://www.pzh.gov.pl/page/fileadmin/user_upload/raport/ Raport.pdf

3. Woolf AD, Pfleger B. Burden of major musculoskeletal conditions. Bull WHO 2003; 81: 646-656.

4. Stan zdrowia ludności w 2009 r. GUS, Warszawa 2011.

5. Orzeczenia lekarzy orzeczników ZUS o niezdolności do pracy wydane w 2010 roku. Zakład Ubezpieczeń Społecznych, Departament Statystyki i Prognoz Aktuarialnych. Warszawa 2011.

6. Wydatki na świadczenia z ubezpieczeń społecznych związane z niezdolnością do pracy w 2010 roku. Zakład Ubezpieczeń Społecznych, Departament Statystyki i Prognoz Aktuarialnych. Warszawa 2011.

7. Verstappen SM, Jacobs JW, Kruize AA, et al. Trends in economic consequences of rheumatoid arthritis over two subsequent years. Rheumatology 2007; 46: 968-974.

8. Boonen A, van der Heijde D, Landewé R, et al. Costs of ankylosing spondylitis in three European countries: the patient's perspective. Ann Rheum Dis 2003; 62: 741-747.

9. Ólafsson S. Social and personal costs of arthritis and rheumatic diseases. An exploratory eurvey. TemaNord 2008; 583.

10. Fries JF, Spitz P, Kraines RG, Holman HR. Measurement of patient outcome in arthritis. Arthritis Rheum 1980; 23: 137-145.

11. Rupiński R, Filipowicz-Sosnowska A. Aktywność choroby a niepełnosprawność $u$ chorych na reumatoidalne zapalenie stawów. Reumatologia 2005; 43: 129-137.

12. Budżety gospodarstw domowych w 2009 r. GUS, Warszawa 2010.

13. Jacobson LT, Lindroth Y, Marsai I, et al. Rheumatoid arthritis: what does it cost and what factors are driving those costs? Results of a survey in a community?derived population in Malmö, Sweden. Scand J Rheum 2007; 36: 179-183.

14. Hülsemann JL, Mittendorf T, Merkesdal S, et al. Direct costs related to rheumatoid arthritis: the patient perspective. Ann Rheum Dis 2005; 64: 1456-1461.

15. Huscher D, Merkesdal S, Thiele K, et al., for the German Collaborative Arthritis Centres. Cost of illness in rheumatoid arthritis, ankylosing spondylitis, psoriatic arthritis and systemic lupus erythematosus in Germany. Ann Rheum Dis 2006; 65: 1175-1183.

16. van den Berg B, Al M, Brouwer W, et al. Economic valuation of informal care: The conjoint measurement method applied to informal caregiving. Soc Sci Med 2005; 61: 1342-1355.

17. Verstappen SM, Boonen A, Verkleij $\mathrm{H}$, et al., on behalf of the Utrecht Rheumatoid Arthritis Cohort Study Group (SRU). Productivity costs among patients with rheumatoid arthritis: the influence of methods and sources to value loss of productivity. Ann Rheum Dis 2005; 64: 1754-1760.

18. Mały rocznik statystyczny 2010. GUS, Warszawa.

19. Verstappen SM, Verkleij H, Bijlsma JW, et al., on behalf of the Utrecht Rheumatoid Arthritis Cohort Study group (SRU). Determinants of direct costs in Dutch rheumatoid arthritis patients. Ann Rheum Dis 2004; 63: 817-824.
20. Westhovens R, Boonen A, Verbruggen L, et al. Healthcare consumption and direct costs of rheumatoid arthritis in Belgium. Clin Rheumatol 2005; 24: 615-619. 